Janez Ferkolj

\title{
Ljubezen do Boga in do Cerkve pri Henriju de Lubacu
}

\section{Love Towards God and the Church in the Life of Cardi- nal Henri De Lubac}

Povz̨etek: V štirih poglavjih pričujočega besedila bralca vabimo k razmisleku o pomenu globoke vere in zakoreninjenosti v Jezusu Kristusu. To omogoča sinovsko ljubezen do Cerkve in ponižno zvestobo do njenega nauka, stkanega skozi stoletja. Cerkev nas skozi stiske časa po svojem učiteljstvu usmerja k živemu izročilu cerkvenih očetov, čistih izvirov iz katerih nam je kardinal Henri de Lubac zajel dediščino vsebin, $s$ katerimi bomo mogli verovati Cerkev v današnjem času.

Ključne besede: Jezus Kristus, Cerkev, vera, sv. Ignacij Lojolski, evharistija, prijateljstvo, cerkveni očetje

Abstract: In four sections of this article we try to invite the reader at reflexion about the sense of deep faith and our rootage in Jesus Christ. This allows us a filial love towards the Church and a humble fidelity to its teaching, formed during the centuries. The Church leads us with her magisterium to a live testimony of Church's fathers and to the pure sources, from which the Cardinal Henri de Lubac took the heritage by which we may believe the Church nowadays.

Key words: Jesus Christ, Church, faith, St. Ignatius Loyola, Eucharist, friendship, Church's father

\section{Uvod}

Teologija ne živi v brezčasnem prostoru. V luči Razodetja, cerkvenega izročila in učiteljstva mora iskati in dati odgovor na žgoča vprašanja vsakokratnega časa. Cerkev preprosto bedi nad tem, da bi v vseh časih in v vseh krajih sprejeli Kristusovo luč, katere zakrament je. Danes je Cerkev v veliki nevarnosti, ker se ponekod pojavljajo razdiralni nagibi do cerkvenega izročila in učiteljstva, ki vso cerkveno zgodovino služita Svetemu pismu. V tem besedilu se bomo skozi oris življenjskih okoliščin francoskega kardinala Henrija de Lubaca poglobili v globine njegovih spoznanj, ki nagovarjajo k pristni ljubezni in zvestobi do Cerkve in njenega tisočletnega izročila, ki je poroštvo edinosti in katoliškosti tudi v prihodnje. 


\section{Henri de Lubac o pomenu prijateljstva}

Morda bi si kdo mislil, da je bil kardinal Henri Sonier de Lubac (20. 2. 1896 - 4. 11. 1991), velikan teološkega znanja in dela v 20. stoletju, vedno zaprt vase, med knjigami in v knjižnicah. Imel je veliko prijateljev: Robert Hamel, Yves Montcheuil, Gaston Fessard, Charles Nicolet, Auguste Velensin, André Ravier, Teilhard de Chardin, Hans Urs von Balthasar ... Bili so mu bratje, opora in misleci, ki so ga spodbujali pri njegovem življenju iz vere in pri delu. Skupaj z njimi je tlakoval pota Boga. Znal se jim je zahvaliti za navzočnost in ji poklicati na pomoč: "Kako bi se vam lahko dovolj zahvalil za bratsko pomoč, ki mi jo že toliko let prinašate s tolikšno potrpežljivostjo in obzirnostjo. In kako naj se dovolj zahvalim Bogu za prijatelja, ki mi ga je podaril v vas? Šibek sem in tega pred vami ne skrivam. To veste že dolgo. Močno se zavedam svoje revščine v vseh pogledih. Dragi Robert, poglejte na križ in Gospoda prosite zame. Pomagajte mi zdržati. " (Chantraine 2009, 722) De Lubac je v ljudeh, ki jih je srečeval, videl Gospodove poslance. Prijateljstvo je med teološkimi razpravami danes skoraj povsem zamrlo. Prijateljstva ni cenil le med svojimi bližnjimi, ampak tudi v njegovi gostoljubnosti pri razmišljanju drugih ljudi, s svojo kritično budnostjo, zahtevnim dialogom. Vedno je znal sprejeti misel drugega, naj je bil še tako drugačen, ki jim je znal in hotel tudi odgovoriti: dokaz za to so njegova dela o ateizmu in budizmu. Tako nam je pokazal pot, kako naj krščanstvo ne bo nikoli protikultura. Noben kristjan se ne bi smel zadovoljiti s povsem odmaknjenim življenjem ali v popolnem nasprotju s svetom svojega časa. To bi pomenilo slabo poznavanje Božjega daru, ki se ne omejuje na vidne meje Cerkve. Veliko nevarnost bi predstavljalo ločevanje krščanstva od človeškega življenja, odrekanje njegove možnosti srečevanja z brati in sestrami. Neobhodna vsebina krščanskega poslanstva je prav prijateljstvo.

\section{Duhovno življenje pri Henriju de Lubacu}

Življenje Henrija de Lubaca je bilo vedno zaznamovano s preizkušnjami v trpljenju. Ko je bil star 20 let, je bil ranjen v uho med bitko pri Verdunu (1917). V letih, ko se vsakdo razcveti, se on ni mogel okleniti ne fizičnega ne intelektualnega dela. Svojo jezuitsko formacijo je preživel bolj v čutenju svojih slabosti kot moči, vse svoje veliko delo je napravil ob hudih bolečinah v glavi. Tako lahko bolje razumemo njegove osebne zapise, ki nikakor niso zgolj misli za lepši dan, ampak globoka izpoved vere pod bremenom križa. »Mislim, da je dobro, da se pogosto spominjamo, da smo neskončno bolj v Božjih rokah, kot bi to lahko razumeli; da smo njegovi ljubljeni otroci, a tudi nekoristni služabniki, da se bodo njegovi nezmotni načrti končno uresničili mnogo bolje, kot jih lahko dojamejo naša najvišja pričakovanja, kajti če se na svoje želje še tako navezujemo, se ustavijo pri videzu, medtem ko Bog, ko se zdi, da jih zamori, v nas in po nas gradi božansko resničnost. " (Chantraine 2009, 588) Ob telesnih mejah se je srečeval tudi z duhovnimi mejami: „Pogum ni vedno velik; žal mi je, da nisem našel Boga in iščem ga tako malo in tako slabo! Sprejetje moje telesne nemoči je nekaj, s čimer moram začeti vsak dan; tako da ugotovim svoje malo delo in neuporabnost.« (247) Prekipevajoča intelektualna rodovitnost 
de Lubacovega življenja vedno odstira isto korenino: vero, absolutno zaupanje v Boga, ki deluje navkljub vsemu. Ta gotovost, da je v Božjih rokah, namaka vse njegovo duhovno življenje in teološko delo: „Obrniti se na Boga, kakor da je vse odvisno od njega, delati, kakor da je vse odvisno od nas; ali še natančneje: moliti, kakor bi bilo vse odvisno od nas, delati, kakor bi od Boga ničesar ne pričakovali. To je bilo zelo ljubo načelo sv. Ignacija Lojolskega. V njem se izraža paradoks, ki je v temelju krščanskega življenja. (de Lubac 2011, 35; 37-38)

Duhovne vaje sv. Ignacija so de Lubaca, ki je pripadal jezuitom, spremljale vse življenje. Začnejo se z razglabljanjem o Jezusu Kristusu. Osvojil ga je Kristus in na vsako stvar je gledal v luči nepresegljivega Božjega daru: Božja skrivnost, razodeta in dana v Jezusu Kristusu. Drugi temelj njegovega razmišljanja je skrivnost človeškega bitja, ustvarjenega za Boga. V Bogu je vse človeštvo poklicano k občestvu, »da bi bili eno«. Med de Lubacovimi značajskimi potezami izpostavimo njegovo razpoložljivost Božjemu delovanju. To ne pomeni umika, ampak pogumno potrditev velikega zaupanja v Boga: On je tisti, ki deluje, prvi. Umik od samega sebe se odraža v dialogu z bližnjim. Vse življenje se je brez strahu soočal z najrazličnejšimi mislimi in duhovnostmi. V svetu, ko ljudje, politični in verski režimi sramotijo skrivnost Boga in človeka, se je znal tudi trdo braniti. Njegovo upanje je bila Cerkev, njegov biotop. $\checkmark$ njenem naročju se je spoprijemal z najostrejšimi nasprotovanji, a je tam našel tudi največje prijatelje. Človeške in duhovne vezi je sprejemal kot spodbudo pri služenju svoji poklicanosti biti človek, jezuit in teolog. Nenehno je bil povezan s Svetim pismom. Preko liturgije in izročila, še posebej Origenovega, je spoznaval, kako je Božja beseda oživljajoča. Koliko časa je posvetil poglabljanju evharistične vere ter kazal na tesno povezanost v različnostih Kristusovega telesa: zgodovinsko, zakramentalno, cerkveno telo. Opomnil je, da kristjan svojo glavno oporo najde v Cerkvi in je v pripravljenosti za Božje delovanje, ki človeštvo vleče k zadnji prihodnosti: Božjemu kraljestvu. Ob spoznavanju, kako velik je Bog se je spogledoval s mističnim hrepenenjem po transcendenci, tem vedno višjim in daljnim, odgovarjajoč z geslom svojega reda: Vse za večjo Božjo slavo. Bog, vedno onstran, in njegova vedno večja slava ... To ne pomeni Sizifovega preklestva, ko nikoli ne doseže vrha, temveč vedno znova porajajočo srečo, ko človek nenehno odkriva nove globine Božje ljubezni.

\section{Henri de Lubac, zazrt v Kristusa}

Med številnimi de Lubacovimi deli (več kot 40) ne najdemo nobenega, ki bi bilo neposredno posvečeno Jezusu Kristusu. A je bil kljub temu ves prežet z njim ter posebej občutljiv na Kristusovo novost. Lahko bi rekli, da je bil leitmotiv njegovih številnih navedkov sv. Irenej: "Kristus je s svojim učlovečenjem prinesel vso novost.« Ponavljajoče se začudenje odseva v zapisu: „Pred našimi očmi se neprestano dogaja čudež. Danes kakor nekoč Kristus prinaša v naše duše pomlad. Danes kakor nekoč po kreposti krščanstva vse stvari postanejo nove.« (2006b, 396) Po le nekaj mesecih predavanj na univerzi v Lyonu je mladega teologa de Lubaca dekan prosil, če bi pripravil predavanje o zgodovini religij. Mladi profesor je delo 
sprejel in se potopil v obsežne snovi o budizmu. Po nekaj letih je postal prvi poznavalec študij o budizmu na Zahodu, snovalec dialoga med budizmom in krščanstvom. Toda vedno znova se je vračal h Kristusovi podobi, ki je brez primerjave $v$ zgodovini človeštva. Isti zanos odkrijemo pri študiju o zahodnem ateizmu. Z Jezusovim učlovečenjem se je zgodilo nekaj korenito novega, enkrat za vselej. Kakšna je ta novost? $V$ kenozi Boga $v$ človeško naravo. Kristus dušam, ki so se dušile $v$ poganstvu in antičnem brezupu, podrejene neizprosni usodi, prinaša prihodnost: »Jez, ki preprečuje pretok valovom ljubezni, je porušen. Bog je ljubezen in v velikem dejanju Ljubezni prihaja prijet grešnega in bednega človeka. Človek in Bog se objemata v Kristusu." (392-401)

Leta 1944 je izšlo de Lubacovo delo Corpus mysticum, najpomembnejša knjiga o evharistiji in Cerkvi v srednjem veku. Poudariti želi, da ima evharistija cilj: izgrajevati Cerkev, zbirati odrešeno človeštvo. $V$ poudarjanju edinosti med Jezusovim zgodovinskim telesom, rojenim iz Device Marije in evharističnim telesom ne smemo prezreti, da je evharistija prehod, pot k Bogu. Noben zakrament ni samemu sebi namen, vsi so sijajne moči, ki vernike vlečejo k prihodnosti, k Bogu. "Kolikor traja ta svet, še vedno živimo v zakramentih, se pravi, kakor razlaga sv. Gregor Veliki, še ne $v$ dokončnem bivališču, ampak na pol prekoračenem začetku, $v$ prehodu vrat. Naša velika noč je Kristus, a je vedno prehod.« $(2010,221)$ Vsako telo nosi v sebi naslednje: Kristusovo telo je bilo na začetku gorčično zrno, samo. Sedaj, po smrti, raste na oltar in rodi sad ter dviga k sebi v nebeške žitnice rodovitno zemljo, $v$ naročju katere je raslo. Preden je Cerkev institucionalna, je občestvena in sloni na moči Boga, ki deluje v evharistiji. Evharistija gradi Cerkev. Prav v slednjem je sidrišče teološke misli o Cerkvi. Cerkev je najprej evharistična, šele potem institucionalna. Zagotovo jo določa človeško delo, a je najprej in predvsem odeta z Božjo milostjo, z močjo, ki dviga zemljo k Stvarniku. Evharistija ni niti cilj niti stvar, saj verujočega spreminja z vero: „Evharistični kruh ni navaden kruh: v sebe preobraža tiste, ki jih hrani iz svoje snovi. Evharistični kruh je telo, od katerega tisti, ki ga uživajo, postanejo jed." (79-80) Evharistija je popotnica za večno življenje: »Evharistija ni obrnjena k preteklosti, ampak v prihodnost in je zakrament upanja, vidno znamenje miru in edinosti, za katero je Kristus umrl in $\mathrm{h}$ kateri hrepenimo prežeti z njegovim Duhom. " (80) Evharistija je zakrament tistega, kar moramo postati. Vsi zakramenti, najprej pa evharistija, so uravnani na našo človeško naravo, ki se nahaja med vrati, se pravi še vedno $v$ času in prostoru, toda na poti $k$ večnosti. »ej, sicer bo pot zate predolga ( $1 \mathrm{Kr} 19,7)$, je rekel angel preroku Eliju. Evharistija je kruh na poti k Bogu, hrana za pot življenja. Papež Benedikt XVI. je ta pogled obnovil v svoji posinodalni apostolski spodbudi: "Evharistija nas vodi v Jezusovo dejanje darovanja. Ne sprejemamo torej samo statično učlovečene Besede (Logosa), ampak nas zajame dinamika njegovega darovanja. On nas priteguje $\mathrm{k}$ sebi. Bistveno spremenjenje kruha in vina $\mathrm{v}$ njegovo telo in kri postavlja $\mathrm{v}$ stvarstvo načelo radikalne spremenitve kot nekakšne »jedrske cepitve«, če naj rabimo ta danes znan izraz, ki nas uvede $v$ srčiko biti, to je spremenitve, ki naj prebudi proces preoblikovanja stvarnosti; zadnji cilj tega pa je prenovitev vsega stvarstva, vse do tega, da bo Bog vse v vsem (1 Kor 15,28).« (Benedikt XVI. 2007, 11) 
Henri de Lubac v svojih delih, še posebej v Histoire et Esprit. L'intelligence de l'Ecriture d'après Origène, poudarja, da vsak človek sluti, kako ni samemu sebi namen, ampak je naravnan na Absolutno, k nečemu, kar ga povsem presega in se mu ne more odreči, ne da bi se izgubil. Bog vedno ostaja skrivnosten in nedoumljiv. Zavest, da Bog vedno presega človeško bitje in njegove zmožnosti, je prav tako v sozvočju s središčem krščanske vere. De Lubac nas svari pred besedami o poznavanju Boga. „Krščanstvo ni stvar, ki bi jo lahko držali v rokah: je skrivnost, pred katero smo vedno nevedni in nezadostni.« (de Lubac 1999, 26) Ne gre za to, da bi zanikali Božje razodetje v Jezusu Kristusu, ampak da bi razumeli, kako ta čezmerna svetloba istočasno odpira nesluteno globino. "Če si razumel, to ni Bog«, je zapisal že sv. Avguštin. Toda ali ne molijo kristjani že od vsega začetka in kličejo Boga za Očeta? To ime nedvomno predstavlja svetli del vere. A pri tem takoj dodajo: "... ki si v nebesih « in s tem zaznamujejo, kako Bog vedno presega človekovo življenje in besede. Bog je v nebesih, onstran. Onstran vsake podobe in misli. »Duha, ki se trudi razumeti Boga, se ne da primerjati s skopuhom, ki zbira kupe zlata, ampak je prej kakor plavalec, ki se zato, da se obdrži na valovih, poganja v ocean in pri vsakem zamahu odrine nov val. Vse bolj in bolj odstira vedno na novo nastajajoče predstave, dobro zavedajoč se, da ga nosijo, a da bi ustaviti se pomenilo umreti.« (2006a, 142)

Duhovno bogastvo v spisih cerkvenih očetov je velikega pomena za razumevanje Svetega pisma. Razodetje je bilo zaupano apostolom in se v celoti predaja njihovim naslednikom. Tako Cerkev gotovosti tega, kar je razodeto, ne zajema samo iz Svetega pisma, ampak tudi iz izročila cerkvenih očetov. Drugi vatikanski koncil je sprožil pastoralno in duhovno prenovo, pri čemer je velikega pomena študij cerkvenih očetov. Patristična misel je zorela ob stiku s problemi pastoralne službe, saj so bili cerkveni očetje večinoma škofje in redovniki. Posredovali so nam vzorce za katehezo, saj so nenehno poučevali katehumene in kristjane. Postavili so temelje krščanskemu izročilu ter nam oprli pot do vseh stopenj mistike, duhovnega življenja. Teologija cerkvenih očetov vidi na delu eno samo Kristusovo skrivnost, ki se tiče vse človeške zgodovine in ima v Kristusu svoj ključ, središče in cilj. De Lubac je posebej veliko sodeloval pri izdelavi dogmatične konstitucije o Božjem razodetju. Spada med poglavitne dele koncila in zasluži stalno pozornost pri poglabljanju katoliške misli. »Naloga obvezujoče razlagati zapisano ali izročeno Božjo besedo je zaupana živemu cerkvenemu učiteljstvu, ki svojo avtoriteto izvršuje v imenu Jezusa Kristusa. To učiteljstvo pa ni nad Božjo besedo, ampak ji služi, ko uči samo tisto, kar je izročeno: po Božjem naročilu in ob podpori Svetega Duha to pobožno posluša, sveto čuva in zvesto razlaga; in iz tega edinega zaklada vere črpa vse tisto, kar predlaga v verovanje kot od Boga razodeto. « (BR, tč. 10) Aktualnost cerkvenih očetov ni aktualnost površja, ampak nečesa, kar daje rodovitnost. "Živeti s svojim časom: to ne pomeni pustiti se voziti na vozu dnevnih običajev in sodelovati pri strasteh množice. Samo tokovi v globini lahko razložijo premikanje površine, samo oni zaslužijo, da se jih lotevamo s širino.« $(1999,28)$ Kadar koli je v našem zahodnem svetu cvetela krščanska prenova tako v redu misli kakor $v$ redu življenja, vselej je cvetela pod znamenjem cerkvenih očetov. 
Vrstica 42. psalma daje glas vzajemnemu klicu Boga in človeka, glas, ki prihaja iz globine, ki ji ni gospodar. Od Boga k človeku in od človeka k Bogu, dve brezni, ki kličeta eno drugo. De Lubac globoko spoznava medsebojni klic teh dveh brezen in ta pogled zapoveduje nauk o človeku, ki ima svojo misel istočasno kot se njegova misel napreza, da bi se človek bolj zavedal tega dvogovora pred njim: »Brezno kliče breznu, glasu tvojih slapov« (Ps 42,8). Človek se takoj znajde v odnosu Boga z njim in njega z Bogom, ki ga v stvarjenju prehiteva. De Lubac mu želi s Cerkvijo povedati, da sta njegovo dostojanstvo in odrešenje iz tega krika narediti svoj osebni klic. Ko de Lubac pravi, da je človek skrivnost in da je ustvarjen po Božji podobi, uporabi jezik Cerkve. Jasno izpostavi, kar oba izraza pomenita o povezanosti med človekom in Bogom. Ko človek sprejme Boga, je njegovo dejanje najvišje in najbolj osebno in ima značaj odgovora in pokorščine. Človek se v resnici pozna samo kot skrivnost, toda ta skrivnost ga razsvetljuje. Brezno pomeni temo, neznano, celo nič. Božje in človekovo brezno nista istega reda. Eno in drugo bi lahko razumeli pod krščansko kategorijo skrivnosti. Kajti brezno, ki je človek, je Božja podoba, podoba, ki neprestano stremi k svojemu upodobitelju. Človek je v sebi skrivnost, v svojem bistvu in v svoji naravi. Ne da bil bil v sebi neskončna polnost skrivnosti, ki se ga dotika in je neizčrpna; ampak ker je v svojem začetnem bistvu bitje naravnano na polnost. „Ni človekov duh prvi, ki se od sveta dviga k Bogu: Bog se preko sveta na neki način spusti do človeškega duha. Naj bo še tako neposreden, dokaz, ki si ga dajemo, pride šele potem. Naj bo še tako vnet, je le posledica. Medtem ko se v človeku izdeluje dokaz, mu to dovoli, povzroči znamenje pred njim, ki ga že vsebuje, ga strese in vedno preseže, ga podarja nekdo drug. Bog zares daje znamenje. Stvari mu služijo za prvi jezik, da govori z ljudmi. Ker je vsaka stvar ustvarjena po Besedi, nam beseda, ki prihaja od njega, govori o njem. Nanjo moramo biti pozorni in ji odgovoriti - a spodbuda ne prihaja od nas.« (2006a, 109-110)

V človeku Jezusu je Bog dokončno izrekel samega sebe: Jezus je njegova beseda in kot njegova oseba je on sam. Razodetje se ne končuje zato, ker bi ga Bog pozitivistično končal, temveč zato, ker je na cilju, kakor je rekel Karl Rahner: „Nič novega ni več povedano, ne kakor da bi ne moglo biti še mnogokaj povedanega, temveč ker je vse povedano, da, ker je vse dano v Sinu Ljubezni, v katerem sta Bog in svet postala eno.« $(1999,193)$ "V Kristusu je dosežen cilj razodetja in v njem cilj človeštva, ker se v njem dotikata in združujeta božanstvo in človečnost. Doseženi cilj ni toga meja, temveč odprt prostor. Kajti zedinjenje, do katerega je prišlo v Jezusu iz Nazareta, mora doseči celotno človeštvo, celotnega Adama in ga spremeniti v Kristusovo telo. Dokler ni pridobljena ta celota, dokler je ta popolnost omejena na eno točko, ostane to, kar se je v Kristusu zgodilo - obenem konec in začetek. Človeštvo ne more priti dlje in višje, kakor je Kristus; vsak navidezni napredek onkraj Kristusa je padec v prazno. Človeštvo Kristusa ne more preseči - zato je Kristus konec; toda človeštvo mora priti vanj - zato je šele on resničen začetek." (193-194) »Kristusova bit je actualitas, prekoračenje samega sebe, exodus, izhod iz sebe; to ni v sebi temelječa bit, marveč dej poslanosti, sinovstva, služenja. In obratno: ta dejavnost ni samo dejavnost, marveč bit, dejavnost, ki sega v globino biti in sovpada z njo. Ta bit je exodus, preoblikovanje. Tako mora na tem mestu 
pravilno umevajoča kristologija biti in inkarnacije preiti v teologijo križa, postati eno z njo; in narobe: dovršena teologija križa, ki se zaveda vse svoje obsežnosti, mora postati kristologija Sina in kristologija biti.« (168)

»Vse je odvisno od križa, in ni druge poti do življenja in do resničnega notranjega miru, razen poti svetega križa in vsakdanjega mrtvenja. Hodi, koder hočeš; išči, kar koli že hočeš: ne boš našel višje poti zgoraj in ne varnejše spodaj, kakor je pot svetega križa. Uravnaj in uredi vse, kakor veš in znaš, in videl boš, da boš moral vedno kaj trpeti, rad ali nerad, in tako boš vedno našel križ. Občutil boš namreč bodisi telesne bolečine, ali pa v duši doživljal duhovno stisko. Včasih te bo Bog zapustil, včasih bližnji gnjavil, dostikrat boš sam sebi nadležen (Job 7,20). Vendar se ne boš z nobeno močjo ali tolažbo mogel rešiti tega stanja ali si ga olajšati, ampak ga boš moral prenašati, dokler bo Bog hotel. /... / Beži, kamor hočeš, ubežati mu ne moreš, kajti kamor koli prideš, neseš sebe $s$ sabo in vedno boš našel sam sebe. Obrni se gor, obrni se dol, obrni se ven in noter: povsod boš našel križ in povsod moraš biti potrpežljiv, če hočeš imeti notranji mir in si služiti večni venec (Lk 21,19; Heb 10,36). « (Kempčan 2011, 145-147)

»Ne glede na področje, kamor kristjana privede razmišljanje, se vedno kakor po naravni sili najde pri češčenju križa. Vsa Kristusova skrivnost je skrivnost vstajenja, a tudi skrivnost smrti. Eno ne more brez drugega in izraža jo ista beseda: Pasha - velika noč. Velika noč je prehod. Skrivnostna umetnost celotnega bitja, popolna ločitev od sebe, ki se ji nihče ne more izogniti. Naj bo uvid, ki navdihuje in usmerja človekovo dejavnost še tako pristen in čist, se mora, da postane resničen, najprej ugasiti. Pokriti ga mora velika senca križa. Za najdenje se je potrebno zgubiti. Duhovna tema, katere trdota se postavlja tako človeštvu kakor posamezniku, se pravi ljubezni do človeka in ljudi kakor tudi ljubezni do sebe. Takšna je vesoljna velika noč, ki pripravlja Božje mesto.« (de Lubac 2003a, 322-323)

»Ljudje so vedno iskali stike in nove možnosti za skupno delo. Gradili so obojestranske povezave na kulturnem, znanstvenem, gospodarskem, ekonomskem in socialnem področju. To brez dvoma velja tudi za teologijo. V dvatisočletnem teološkem izročilu so uresničili že veliko skupnih prizadevanj ... Nobenemu arhitektu ni potrebno pričeti pri točki nič, ker lahko vsak upošteva in tudi mora upoštevati pridobitve prejšnjih generacij. Tako je tudi teolog poklican, da ovrednoti, ohranja in nadaljuje vse, kar je veljavnega in živega v krščanskem izročilu. $V$ iskanju odgovora na aktualna vprašanja časa se je potrebno ravnati po treh temeljnih načelih teologije. To so cerkvenost, znanstvenost ter praktično naravnana odprtost za vprašanja današnjega človeka ... Teologija ne živi v brezčasnem prostoru. V luči Razodetja, cerkvenega izročila in učiteljstva mora iskati in dati odgovor na žgoča vprašanja vsakokratnega časa. Vprašanja pravičnosti, miru in svobode so danes po- 
stala skrajno aktualna ... Teologija je pot Boga k ljudem, sredstvo odrešenja, izžarevanje Božjega veličastva.« (Štrukelj 2000, 130-132)

„Nič se ne ohrani nepoškodovano brez napora. Ponavljanje obrazcev ne zagotavlja prenašanje misli. Razum, ki se zapre sam vase, naj je nabral še takšno bogastvo, svojega zaklada ne more ohraniti v celoti. Posuši se, izhlapi ali zgnije. Vernik, ki meni, da bo enkrat za vselej ostal na določeni ravni v izražanju vere, preneha verovati in misliti z živo Cerkvijo ter se ne le oddalji od podrobnosti ali novih določb, ampak izgubi realnost, temelj vere. " (de Lubac 1999, 13, 75) Za ohranjanje vere ne zadošča zgolj ponavljanje že oblikovanih stavkov. Zaradi pomanjkanja teološke formacije se porajajo herezije. Študij je pomemben zaradi osebne rasti v veri in ker teološka poglabljanja tvorijo zanos evangelizacije. $V$ tem je apostolsko poslanstvo študija. Učiti se, da bi lahko pomagali ljudem spoznavati pristno krščanstvo.

Nemški zgodovinar Aly Götz je za časopis Spiegel izjavil: „Preoblikovati moramo moralne standarde. Ljudje morajo postaviti meje svojim dejanjem in željam. V Svetem pismu je lepo in zelo radikalno opozorilo: Človek je ustvarjen po Božji podobi, ne glede na to, kako bolan, reven ali poškodovan je. To maksimo moramo prenesti v našo sekularno in ustavno samopodobo. « Zgodovina je polna tragičnih primerov, ki kažejo, kaj se zgodi, če ignoriramo to opozorilo. Kakšna napaka je odreči spoštovanje človeškega dostojanstva in se poskusiti igrati Boga. (Trontelj 2014, 102-103)

Tako za de Lubaca kot za celotno krščansko izročilo velja, da je nemogoče krščanstvo spustiti na moralne vrednote, naj bodo še tako vzvišene kot odpuščanje in bratska ljubezen do ubogih. Novost krščanstva ni utemeljena v nauku, ampak v učinkovitosti Kristusovega prihoda. Učlovečenje namreč ni dogodek iz preteklosti, mrtva stvar, o kateri bi kristjani ohranjali pobožen spomin. V veri se ponavlja v duši vernika. Po večni tišini, v katero je po Očetu večno izrečena Beseda, po tišini v Betlehemu, je sedaj tretja tišina, zbiranje teme v duši, ki mora sprejeti svojega Odrešenika. Zato se največje znamenje krščanstva po de Lubacu ne nahaja v teoloških globinah ali v veličastju liturgije, temveč v ponižnih pričevalcih, ki so pustili, da se je v njih Kristus ponovno učlovečil. »Bogovdanost je modrost, ogibati se hudega je vednost. Modrost se nanaša na zrenje, vednost pa na delovanje. Bogočastje pa je ljubezen do Boga, s katero zdaj hrepenimo po tem, da bi ga videli, in verujemo in upamo, da ga bomo gledali; in kolikor napredujemo, ga zdaj gledamo z ogledalom, v ugibanju, takrat pa očitno. To je namreč tisto, o čemer govori apostol Pavel: iz obličja v obličje.« (Avguštin 2014, 395-396)

\section{Henri de Lubac, zazrt v Cerkev}

„Tvoje upanje je Cerkev!« S temi besedami nas de Lubac v globoki veri naposled postavi pred skrivnost Cerkve; za razumevanje skoraj težja skrivnost kot tista o Bogu. Kdo ni v Cerkvi nikoli našel ali celo trpel zaradi ozkosrčnosti, preveč človeških želja, farizejstva, obsojanja, obrekovanja ... Vse to, kar najdemo v družini ali v družbi obstaja tudi pri kristjanih, laikih in klerikih. Kako potem govoriti o Cerkvi kot zatočišču in odrešenju? 
Henri de Lubac še zdaleč ni bil teolog, ki bi bil deležen časti ali uglednih povabil. Prepovedali so mu poučevanje teologije in celo pisanje knjig. Prav iz tistega najtežjega obdobja so njegove slovita Meditacija o Cerkvi. Trpel je zaradi Cerkve, a je ni nikoli zanikal. »Ne loči se od Cerkve! Nobena sila nima svoje moči. Tvoje upanje je Cerkev. Tvoja rešitev je Cerkev. Tvoje zatočišče je Cerkev. Višja je od neba in širša od zemlje. Nikoli se ne postara: njen obstoj je večen. « (de Lubac 2003b, 185) Lahko bi ga imenovali preroka Cerkve. Prav omenjeno delo je pozneje doživelo velik razcvet in bilo prevedeno $v$ vse svetovne jezike ter vplivalo na koncilske očete drugega vatikanskega koncila. Vrnil se je k izvirom, da bi pokazal na globoko edinost Cerkve. Ne le zemeljsko, ne le duhovno, temveč hkrati nebeško in zemeljsko, hierarhično in karizmatično, sveto in grešno, vidno in nevidno. Pokazal je na skrivnost ene Cerkve, kjer Božja milost potuje preko mesa in teme, paradoks, tako podoben največjemu paradoksu: učlovečenju. »Cerkev, vsa Cerkev, edina Cerkev, tista od včeraj in danes in jutri, je zakrament Jezusa Kristusa. V resnici ni nič drugega.« (184-185) Enaindvajseto stoletje je polno neuresničljivih sanj o popolni Cerkvi, individualističnih krivin, pastoralnih aktivizmov, obžalovanj in reformnih nepotrpežljivosti. Kristjani so v nevarnosti, da izgubijo izpred oči središče svoje vernosti: da je Cerkev skrivnost. To pomeni, da ni njihova, ampak da je del načrta Božje ljubezni. Bog bo preko svoje čudovite in pomilovanja vredne Cerkve vedno lahko obiskal in ozdravljal človeštvo: „Ljudje se lahko odpovedo Svetemu Duhu, Sveti Duh pa se ne bo nikoli odpovedal Cerkvi. Vedno bo Kristusov zakrament. Vedno nam ga bo v resnici ponavzočevala. Ko se zdi, da daje znake utrujenosti, že nekje neopazno klije nova pomlad in kljub vsem oviram, bodo vedno rastli svetniki. « (203) To pomeni stavek: »Tvoje upanje je Cerkev. « Ne strastno občudovanje ali aroganca o vedno zmagovalni Cerkvi, ampak silno zaupanje v Boga, Gospoda in Rešitelja Cerkve. »Hvaljena bodi, Mati lepe ljubezni, rešenjskega strahu, Božjega vedenja in svetega upanja! Živa ladja, vzhodna vrata! Čisto ogledalo delovanja Najvišjega! Ljubljenka Gospodarja vesoljstva, seznanjena z njegovimi skrivnostmi, ki nas učiš, kaj mu ugaja! Tvoj nadnaravni sijaj ne zbledi niti v najhuših časih! Ti si milost, v katero je naša noč obdana s svetlobo! Ti nam vsak dan daješ Tistega, ki je edini pot in resnica. Po tebi imamo vanj upanje za življenje. Sveta mati, enkratna in brezmadežna! Velika Mati! Sveta Cerkev, resnična Eva, edina prava Mati živih!« (239-240)

\section{Zaključek: Na potih Boga}

De Lubacovo delo Sur les chemins de Dieu je kakor široko nadaljevanje poti k Bogu, nakazanih pri sv. Tomažu Akvinskem. Obstoj Boga je mogoče dokazati po petih poteh. Prva pot je najbolj razvidna in izhaja iz gibanja. Druga pot temelji na tvornem vzroku, tretja na možnem in nujnem, četrta na stopnjah, ki jih najdemo v stvareh in peta pot, ki temelji na usmerjenosti stvarstva. (Akvinski 1999, 333-340) Pota Boga srečujemo v času, tej reki, ki srečuje prijatelje, brate in sestre. Eden največjih de Lubacovih prijateljev in prevajalcev njegovih del v nemščino, je bil kardinal Hans Urs von Balthasar. V knjigi Srce sveta, ki ji je de Lubac napisal predgovor, beremo: »Je nekaj, kar leti, se uravnava, skrivnostno odteka: čas. Nevidna 
ladja, ki potuje od enega brega na drugega. Brez postanka od enega bivanja k drugemu. Pojdi, povzpni se nanj, čas se že dviga in te nosi, ne da bi vedel kam, niti kako, trdna tla pod tabo že nihajo in se tresejo, trda in mrzla pot postaja mehka in živa, začenja teči kakor reka v milostne vijuge, bregovi se spreminjajo, eden za drugim si sledijo gozdovi, široka polja, mesta in tok je številen in spremenljiv - zdaj miren, zdaj divji ter neukročeno drvi, zdaj spet zbran in razprostirajoč se kakor $v$ prostranost morja.« (Balthasar 2014, 22-23)

„Človek se izgrajuje v zgodovini in po zgodovini, zato se vsak rod dojema kot člen človeštva na poti. Toda potovanje človeštva ne bi imelo nobenega pomena oziroma človeštvo ne bi potovalo in ime samo, po katerem ga orisujemo bi bilo zgolj flatus vocis, če se ne bi v središču sveta nahajal privlačen kot Cilj, Večni, ki v vsakomur izmed nas pusti pečat svojega obraza in vsakemu podeli svojo neskrčljivo notranjost. « (de Lubac 2006a, 224-225)

Kardinal Henri de Lubac je izjemen učitelj in branitelj katoliškega nauka, ki zajema pri čistih izvirih očetov in njihovih spoznanj o Bogu. De Lubac je kljub težkim življenjskim preizkušnjam, ostal neomajno zvest Cerkvi in nas uči edinosti z izročilom in Božjo besedo. Te edinosti nobeno pristno učiteljstvo ne bo nikoli moglo prelomiti. $\checkmark$ tej naravnanosti se kaže tudi naša resnična ljubezen do Kristusa in Cerkve.

\section{Kratica}

BR - Drugi vatikanski vesoljni cerkveni zbor 1980 [dogmatična konstitucija O Božjem razodetju].

\section{Reference}

Akvinski, Tomaž. 1999. Izbrani filozofski spisi. Ljubljana: Družina.

Avrelij, Avguštin. 2014. O Trojici. Ljubljana-Celje: Mohorjeva Družba.

Benedikt XVI. 2007. Evharistija, zakrament ljubezni [Sacramentum Caritatis]. Posinodalna apostolska spodbuda. Ljubljana: Družina.

Chantraine, Georges. 2009. Henri de Lubac. Zv. 2, Les années de formation (1919-1929). Études lubaciennes 8. Pariz: Cerf.

de Lubac, Henri. 1999. Paradoxes. Pariz: Cerf.

-- - 2003a. Catholicisme. Pariz: Cerf.

- - - 2003b. Méditation sur l’Église. Pariz: Cerf.

- - - 2006a. Sur les chemins de Dieu. Pariz: Cerf.

- - . 2006b. Affrontements mystiques. Pariz: Cerf.

- - - 2010. Corpus mysticum. Pariz: Cerf.

- - - 2011. Le rythme paradoxal. V: Bulletin de
I'Association Internationale Cardinal Henri de Lubac. Zv. 18. Pariz-Namur: s.n.

Drugi vatikanski vesoljni cerkveni zbor. 1980. Koncilski odloki. Ljubljana: Nadškofijski ordinariat.

Ferkolj, Janez. 2016. Prenova iz izvira: Kardinal Henri de Lubac kot interpret cerkvenih očetov in živega izročila. Ljubljana: Teološka fakulteta.

Kempčan, Tomaž. 2011. Hoja za Kristusom. Celje: Mohorjeva Družba.

Strle, Anton. 1998. Teologi za prihodnost. Ljubljana: Družina.

Štrukelj, Anton. 2000. Klečeča teologija. Ljubljana: Družina.

- - - 2015. Zaupanje in pogum. Ljubljana: Družina.

Trontelj, Jože. 2014. Živeti z etiko. Ljubljana: Inštitut za etiko in vrednote.

Von Balthasar, Hans Urs. 2014. Le coeur du monde. Pariz: Saint-Paul. 